\title{
IS THERE A TREND OF EUROIZATION OF EU COUNTRIES STILL USING THEIR NATIONAL CURRENCIES? TRADE AND INVOICING
}

\author{
Jan Mačí
}

1 University of Hradec Králové, Faculty of Informatics and Management, Department of Economics, Czech Republic, ORCID: 0000-0002-6315-7991, jan.maci@uhk.cz.

\begin{abstract}
Seven of the eight EU countries not yet using the euro as their legal tender undertook to adopt the common currency in the future. However, the actual moment of adoption may influence, e.g. the attitude of the population (households). Other needs for the use of the euro have a business sector that is managed considering current market conditions and opportunities. The prerequisite of this article is that within the non-EMU EU economies, due to the close ties to EMU members and the prospect of a future, albeit often uncertain, approach to the euro area, the gradual euroization of businesses takes place. Among other things, euroization should be reflected in foreign trade, namely in the currency of invoicing. Using the Eurostat data from 2010-2018 on import and export and the currency of non-EMU countries invoicing to third countries expressed in EUR, USD, national and other currencies, the links between invoicing currency, size of economies and exchange rate regime were sought. The aim was also to describe the actual trend of invoicing international trade to third countries outside the EU. According to the results of the analysis, it was found that the block of non-EMU countries rather euroizes and the importance of the national currency is rather declining. The level of growth of the share of the euro and the decline of the national currency has a different intensity for imports and different for exports. At the same time, it was found that in the case of imports in EUR and NC and exports in EUR, a possible relationship between the invoicing currency and the exchange rate regime can be identified. Last but not least, it was found that in the case of invoicing in EUR and NC (national currency), there is a relationship between the size of GDP and the invoicing currency.
\end{abstract}

Keywords: Euro, currency union, foreign trade, invoicing, integration.

JEL Classification: F14, F15, F36.

APA Style Citation: Mačí, J. (2020). Is There a Trend of Euroization of EU Countries Still Using Their National Currencies? Trade and Invoicing. E\&M Economics and Management, 23(4), 182-196. https://doi.org/10.15240/tul/001/2020-4-012

\section{Introduction}

Once entering the European Union, the Czech Republic as well as at present six other countries which are not currently members of the EMU committed to accept common currency - the euro. For example, Sweden accessed in 1995, the Czech Republic in 2004 and these two countries are still using their national currencies. By coincidence, these two countries use for payments their crowns - Czech koruna, respectively Swedish kronor. What is more, in case of these two countries, a date of EMU accession has not been set yet. In fact, due to several major unfortunately rather negative, economic events that have taken place over the last decade (i.e. financial crisis, debt crisis), and due to several ongoing economic problems of the Eurozone (e.g. significant public debt burden for Greece or Italy; the budgetary problems of Italy and, to some extent, France; responsibility for indebtedness of national economies, etc), the relevant EU institutions do not even put pressure on countries still using their national currencies in order to fulfil the commitment of euro adoption. 
Certain deficiencies in the functioning of the euro area as such (see, e.g., De Grauwe, 2016; or Dosi et al., 2019) as well as public opinion on the euro in particular countries seem to deter the pressure on these national economies to adopt the euro. The European Commission via its initiative - Eurobarometer - regularly monitors support for the euro adoption and perceptions of single currency benefits in countries still using their national currency as a legal tender (hereinafter referred non-EMU members). The percentage support rate of the euro adoption in non-EU member states within the years 20122019 is presented in Tab. 1 below.

There is missing Denmark in Tab. 1 that has a permanent opt-out, which means that Denmark has no obligation to adopt the euro. Thus, monitoring Danish attitude towards the euro is quite irrelevant. At the same time, Tab. 1 does not contain Great Britain which left the EU on February 1, 2020. It means, there are currently 8 non-euro countries in the EU. These 8 countries represent a market comprising approximately 105 million inhabitants with an economic output of EUR 1,910.9 billion (according to Eurostat; year 2018), which is about $23 \%$ of the EU population with a share of about $14 \%$ of GDP.

Tab. 1 shows that the country with the lowest support for the introduction of the euro in its territory is Sweden (36\% in 2019; minimum of $30 \%$ in 2016 ) closely followed by the Czech Republic (39\% in 2019; minimum of $12 \%$ in 2012). On the other hand, there are two countries in which the support of the euro introduction exceeds $60 \%$. In particular, support in Romania amounted to $61 \%$ in 2019 (cf. maximum of $74 \%$ in 2014) and support in Hungary reached $66 \%$ in 2019 (cf. minimum of $54 \%$ in 2013). However, as regards the trends in these two euro-inclined countries, in Romania the trend is rather downward, while in Hungary it is increasing. It is certainly worth mentioning Sweden, which has been a member of the EU since 1995, i.e. the longest of all listed in the table. Sweden does not apply permanent opt-out as Denmark does. However, Swedes refused euro adoption in the referendum in 2003 when $56 \%$ of voters voted against the euro.

Regarding the observable trends, Tab. 1 shows that Bulgaria, Croatia and Romania

\section{Tab. 1: Opinion polls in member states yet to adopt the euro (support for euro in \%)}

\begin{tabular}{l|c|c|c|c|c|c|c|c|c} 
Country/year & $\mathbf{2 0 1 2}$ & $\mathbf{2 0 1 3}$ & $\mathbf{2 0 1 4}$ & $\mathbf{2 0 1 5}$ & $\mathbf{2 0 1 6}$ & $\mathbf{2 0 1 7}$ & $\mathbf{2 0 1 8}$ & $\mathbf{2 0 1 9}$ & 5Y Trend (slope) \\
\hline Bulgaria & 53 & 52 & 51 & 55 & 47 & 50 & 51 & 47 & $\begin{array}{c}\text { slightly decreasing } \\
(-1.2)\end{array}$ \\
\hline Croatia* & - & - & 55 & 53 & 48 & 52 & 47 & 49 & $\begin{array}{c}\text { slightly decreasing } \\
(-0.9)\end{array}$ \\
\hline Czech Republic & $\mathbf{1 2}$ & $\mathbf{1 3}$ & $\mathbf{1 5}$ & $\mathbf{2 9}$ & $\mathbf{2 9}$ & $\mathbf{2 9}$ & $\mathbf{3 3}$ & $\mathbf{3 9}$ & $\begin{array}{c}\text { growing } \\
(+2.4)\end{array}$ \\
\hline Hungary & 58 & 54 & 64 & 60 & 57 & 57 & 59 & 66 & $\begin{array}{c}\text { growing } \\
(+1.4)\end{array}$ \\
\hline Poland & 44 & 38 & 45 & 44 & 41 & 43 & 48 & 46 & $\begin{array}{c}\text { slightly growing } \\
(+1.1)\end{array}$ \\
\hline Romania & $\mathbf{6 4}$ & $\mathbf{6 7}$ & $\mathbf{7 4}$ & $\mathbf{6 8}$ & $\mathbf{6 4}$ & $\mathbf{6 4}$ & $\mathbf{6 9}$ & $\mathbf{6 1}$ & $\begin{array}{c}\text { slightly } \\
\text { decreasing } \\
(-0.9)\end{array}$ \\
\hline Sweden & NA & NA & NA & 32 & 30 & 35 & 40 & 36 & $\begin{array}{c}\text { growing } \\
(+1.8)\end{array}$ \\
\hline Non-EMU total & 47 & 45 & 52 & 49 & 45 & 47 & 51 & 49 & $\begin{array}{c}\text { slightly growing } \\
(+0.6)\end{array}$ \\
\hline
\end{tabular}

Source: Mačí (2019, p. 214), edited.

Notes: The figures are a sum of the answers 'very much in favor' and 'rather in favor' of introducing the euro. Data were collected for the fourth month of the year.

${ }^{*}$ Croatia is a member state of the EU since $07 / 2013$ thus opinion polls for 2012 and 2013 are not available. 
experienced drop in support between initial and end observation (Bulgaria and Croatia -6 percentage points, Romania -3 p.p.; at the same length of observation - i.e. from 2014 to 2019 - the values would slightly change to -4 p.p. in case of Bulgaria and -13 p.p. for Romania). On the contrary, the most significant increase is observable in case of the Czech Republic (+27 p.p.).

Various opinion polls show - at least on the example of the Czech Republic - a slight difference in opinion on the euro adoption between different parts of society, such as between households and companies and more pronounced differences among businesses as such (see, e.g., Knížková, 2018). The opinion of the population of the EU countries as a whole not yet using the euro is represented by Tab. 1. Regarding the business sector, the attitudes towards the euro differ. Particularly those companies that export to EMU countries, respectively companies that invoice their exports/imports in euros would probably like to replace the national currency (NC) with a common currency. It can also be assumed that companies incorporated in multinational chains (MNC) and concerns, and other enterprises with a significant share of foreign ownership, or national enterprises that do not have the power to assert their national currency as invoicing one, would also welcome the introduction of the euro as a legal tender. Such enterprises may subsequently have an effect on a certain 'spontaneous' euroization of the whole economy. The term 'spontaneous euroization' has been already used by authors Horníková et al. (2005). In their article, they present data obtained by the Czech National Bank (CNB) from the early phase of the physical existence of the euro, i.e. from the years 2001-2003. These data and authors' comments practically confirm the above-stated theses, albeit on a different timeline.

The situation regarding the potential growth in the number of euro area members, to say the final euroization of an economy, now appears as follows. The candidate states enter or plan to enter the Eurozone individually, not in blocks. At the same time, these states have theoretically the possibility of postponing their entry until they consider themselves ready. This provides a unique opportunity to study a wide range of elements and circumstances related to the creation of an optimal currency area.
This article seeks to fill a research gap in the field of international trade and its invoicing when exporting/importing businesses come from an EU Member State that is not a member of the EMU. At the same time, the research will suitably complement the ex-ante view of the optimum currency areas, which assumes that the introduction of the single currency will ex-post strengthen international trade. So, in such a situation, is there an euroization of international trade ex-ante? If the answer is yes, then such a finding can be useful for both the private and public sectors. For example, the issue of exchange rate hedging may be crucial for the private sector both for non-financial corporations seeking exchange rate hedging and for financial corporations offering exchange rate hedging. The public sector, in turn, can better specify and present its position and policy towards the common currency.

Based on the above stated the research aim of this article is to find out whether, or with what trend and under what circumstances participation in the economic union with the potential to participate in monetary union entails changes in the invoicing of international trade.

In order to reach the goal, this article continues as follows. First, based on the literature review, the euroization and its manifestations in the field of international trade on the example of invoicing are described. Subsequently, the research methodology is presented, including the presentation of the analyzed data. The following chapter contains the research results, discussion of the results and finally the conclusion.

\section{Euroization}

If there exists or occurs a large economic area with a single currency of a high quality and economic subjects from such area are active in cross-border economic activities then such a currency naturally gains influence and asserts itself in international transactions. For pushing one currency at the expense of the other, the theory knows terms as dollarization, euroization, etc. This article, given its focus, works with the term 'euroization'.

As Horníková et al. (2005) state, euroization can take two forms - official or spontaneous. The official euroization means that a country will become a full member of the countries using the common currency (i.e. joining the euro area). Unofficial or spontaneous, alternatively natural 
euroization consists in replacing the domestic currency with a foreign currency (the euro) of the pure will of firms and households. An extreme case of spontaneous euroization is the situation where the whole state moves unilaterally to use foreign currency. Such a country does not participate in operations of the central bank managing the replacing currency, because the country is not a member of the official structures (Montenegro is a current example in Europe). Mainly due to the loss of monetary instruments, including the function of the central bank as a lender of last resort, as well as the uncertain benefits of long-term euroization, for example Rochon and Rossi (2003) warn against the unilateral adoption of the euro (or US dollar).

Scientific articles and publications deal with the topic of euroization or dollarization at various levels, be it at the banking sector (e.g. Xhelili, 2016; Bošnjak, 2018), non-financial corporations, households (Beckmann, 2015) or the economies as a whole (see, e.g., Horníková et al., 2005; Ivanov et al., 2011; Udoh \& Udeaja, 2019). The impact of the introduction of the single currency on trade is often monitored (see below, e.g., Rose, 2000; Bun \& Klaasen, 2007; Mika \& Zymek, 2018). Almost all similarly focused contributions have an overlap with the topic of optimal or at least common currency areas.

From the perspective of the optimum currency area theory, it should be possible to observe whether the so-called 'coronation theory' is being fulfilled in EU Member States that do not yet have the euro as their official currency. Thus, whether such economies are converging in such a way that, due to their very close and intense economic-political links with euro area members, they should be able to switch to a common currency with minimal economic costs and minimal risk of so-called asymmetric shocks; in other words, the benefits of membership should outweigh the costs.

Vice versa, from the perspective of alternate theory to the coronation, i.e. socalled 'train theory', it should be observable on the example of newcomers to the euro area whether this theory is being fulfilled, for example, by the increased intensity of trade between them, which in turn should mean a reduced risk of asymmetric shocks. About the relationship between trade exchange and the risk of asymmetric shocks, see, e.g., De Grauwe (2018). As for the link between the common currency and trade exchange, for example, Rose (2000) on the data he analyzed using the gravity model concludes that the common currency promotes international trade very significantly. On the other hand, Bun and Klaasen (2007), who take as their starting point researches mentioning the benefits of the single currency to international trade in terms of growth of $5 \%$ to $40 \%$, achieve only about $3 \%$ benefit after model revision. Similarly, Mika and Zymek (2018) do not observe that accession to the EMU would result in a significant boost in international trade.

\section{EU Countries Still Using Their National Currencies and the Eurozone - Intra and Extra-EU Trade}

The Czech Republic, Sweden, Denmark, Romania, Bulgaria, Poland, Hungary, and Croatia are EU members, however, from the point of view of integration stages, integration within the economic and monetary union has not been completed. I.e., these countries are still using their national currency (NC) as their legal tender. Until recently, the United Kingdom was a separate case. The UK not only had never been a member of the euro area; this country even had a negotiated opt-out from adopting the euro. And above all, the UK completely left the EU in February 2020. At the same time, it is appropriate to clarify the position of Denmark, Bulgaria and Croatia.

On the one hand, Denmark is not the member of the Eurozone. On the other hand, Denmark operates in ERM II currency regime with the oscillation band $\pm 2.5 \%$, which is much narrower than $\pm 15 \%$ fluctuation band that ERM II allows (The IMF ranks Denmark among the group of countries using the currency regime conventional peg). Croatia does not participate in ERM II, however, the exchange rate of local kuna has been kept stable (according to the IMF classification, it falls into the so-called stabilized arrangement; in fulfilling its primary objective of price stability, the Croatian central bank itself emphasizes the issue of the stability of the Croatian kuna against the euro, given the openness of the Croatian economy and the significant exposure of trade to the euro area (Croatian National Bank, 2015)). As well as Croatia, even Bulgaria does not participate in ERM II. However, Bulgaria has a rate firmly 
tied to the euro in the currency board regime. The rest of the non-EMU countries do not practice fixed regimes. In fact, they operate with managed floating $(\mathrm{CZ}, \mathrm{HU}, \mathrm{RO})$, or free floating (SE, PL) (IMF, 2019, pp. 6-7).

From the above implies, that regarding euroization, there is a relatively large block of countries within the EU that still use the national currency but at the same time these countries have a rich trade exchange with EU countries that have renounced their national currencies in favor of the euro. There also exists a subgroup of countries within the non-EMU members (DK, $H R, B G$ ) that, which given its exchange rate regime, is essentially a 'hidden user of the euro area'.

It is therefore possible to ask what the euro's success is in terms of export/import between EU countries and third countries (socalled extra-EU trade), or in the case of trade between a non-euro area member and a euro area member within the EU (in fact a specific type of intra-EU trade) - see the following chapter.

\subsection{Invoicing in the Euro}

Why is a choice in which currency to invoice important? It is one of the possible ways of exchange rate hedging in the form of so-called natural hedging. For more on the choice of invoicing currency due to various variables (e.g. industry), see, for example, Ito et al. (2016) who focused on Japan, or Goldberg and Tille (2008) who analyzed driving forces for currency invoicing on the sample of 24 countries. Ligthart and Werner (2012) deal with the economic space that is close to the focus of this article. These authors observed the growing share of the euro as an invoicing currency in the case of Norway (not only a non-euro area member, but even a non-EU member). Ligthart and Werner (2012) add that in the Norwegian case, the euro is gradually gaining ground not only at the expense of the Norwegian crown, but also adopts the position of 'vehicle currency' from the US dollar.

On the other hand, in the case of EU, invoicing in euros between two EU members whether or not they are part of the EMU

\section{Fig. 1: Extra-EU trade in 2010-2018 - shares on imports (upper part) and exports (lower part) by invoicing currency (\%)}

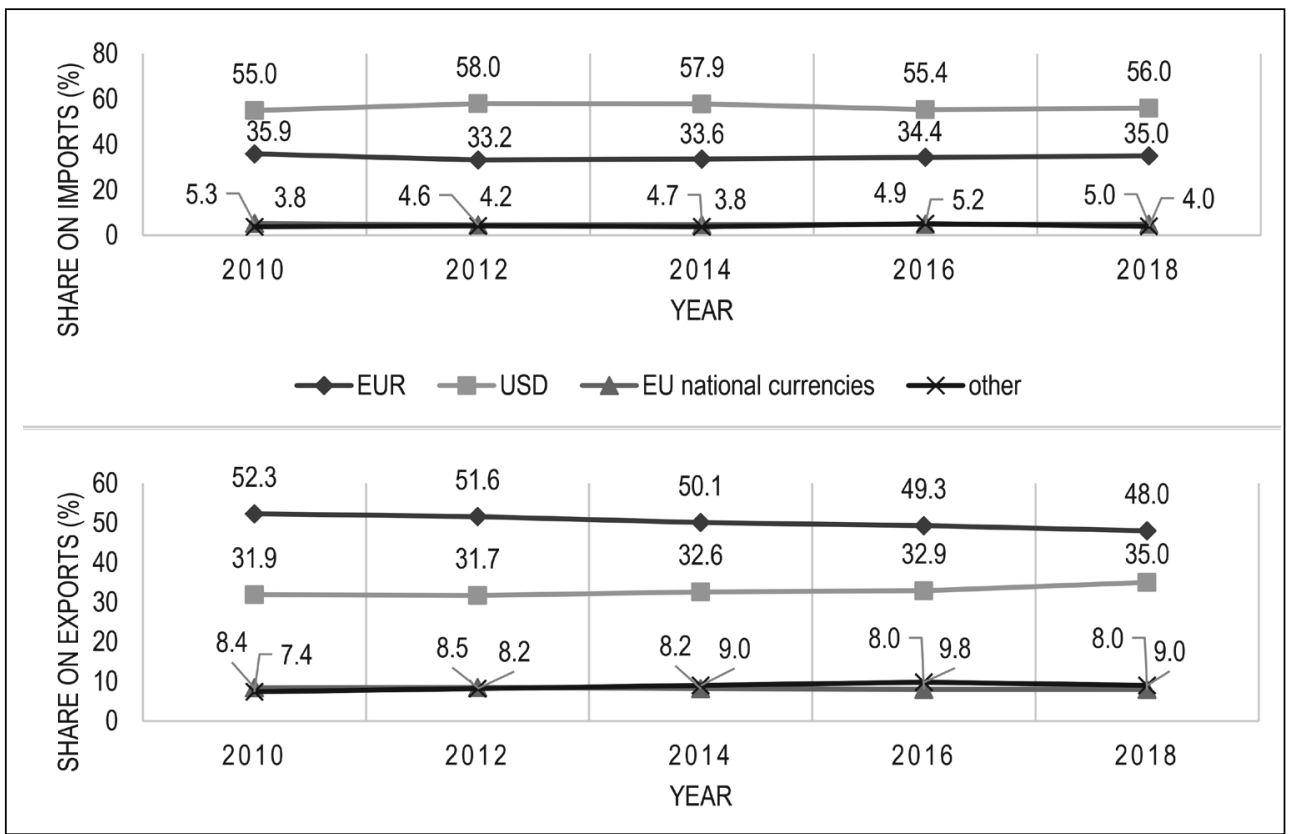


seems quite natural (the exception might be, respectively might have been the Great Britain thanks to the volume of its economy and traditionally strong position of the British pound with the potential to push through GBP as an invoicing currency; Brexit could also have an additional effect).

As regards the invoicing of exports from/ imports to the EU of countries outside the EU, the US dollar (USD) is a major competitor in terms of the invoicing currency. According to Eurostat data (2019) for 2018, for all EU Member States, the US dollar even predominates in EU imports ( $56 \%$ for USD vs. $35 \%$ for EUR). See the upper part of Fig. 1. Moreover, as Eurostat (2019) states, USD is practically a hegemon in terms of oil invoicing (the share was $88 \%$ for the year 2018). In the case of EU exports, on the other hand, the euro is the most widely used currency with a $48 \%$ share; USD share is $35 \%$. The national currencies of non-EMU members account for $5 \%$ and the other currencies $4 \%$ (Fig. 1, lower part). On the other hand, it may be worth mentioning that even in the case of imports, the euro would have a higher percentage, if the oil is excluded (Eurostat, 2019).

Regarding EU-wide trends, Fig. 1 observe the virtually stable position of all currencies on import invoicing. There is a slightly different situation in exports. The euro with the dollar in total holds a stable $83 \%$ share, but the euro slightly lost in favor of the US dollar (EUR 2018$2010-3.7$ p.p.; USD $2018-2010+3.1$ p.p.)

\subsection{Determination of Hypotheses}

The following part of the paper will, in line with the objective, fully focus on invoicing of nonEMU countries. In view of the UK's possibility to promote its national currency as an invoicing one as it was outlined above, the following hypothesis is established:

H1: The percentage share of the currency in export/import invoicing does not depend on the amount of GDP output measured by EUR.

In the case of $H 1$, the question of whether the size of the economy affects the determination of the invoicing currency is examined. Variations for EUR, USD a NC (national currencies of nonEMU states) are monitored. The assumptions are:

- The larger the economy (measured by GDP), the greater the percentage of the national currency in export/import invoicing.
- The smaller the economy, the greater the share of the euro as an invoicing currency.

- The smaller the economy, the greater the share of the dollar as an invoicing currency.

At the same time, with regard to the above presented exchange rate regimes of individual non-EMU economies, a second hypothesis is set:

H2: The percentage share of invoicing currency does not depend on the exchange rate regime.

In $H 2$, it is checked whether the method of determining the NC rate to EUR has an impact on the invoicing currency. It is now assumed that:

- The more the exchange rate is set by the market $(\min =$ currency board; $\max =$ free floating), the smaller the share of EUR or USD.

- The more the exchange rate is set by the market $(\min =$ currency board; $\max =$ free floating), the greater the share of the national currency.

Last but not least, basically a certain influence of time is examined, when here presented research suggests that the longterm participation of non-EMU countries in the economic union leads to a naturally increasing use of the euro and a decline in the share of the national currency. Thus, the following research question is defined:

$R Q 1:$ Has the average share of the euro as the invoicing currency of non-EMU countries a growing trend?

\section{Data and Methodology}

For the purposes of partial analyzes, the data on the size of GDP and on the share of invoicing currencies in imports/exports presented by Eurostat were used. Due to missing data in terms of invoicing currency on intra-EU trade of non-EMU EU members (these data are not monitored within Intrastat; amounts are reported in national currency for non-EMU countries), data related to extra-EU trade for 2010-2018 were analyzed; monitored at twoyear intervals (see Tab. 2).

While this data cannot provide a comprehensive view of the euroization of trade in EU Member States not yet using the euro (in non-EMU countries), at least partial trends can be identified and possible differences and other characteristics in potential euroization of the 


\begin{tabular}{|c|c|c|c|c|c|c|c|c|c|c|c|}
\hline \multirow{3}{*}{$\begin{array}{l}\text { Member } \\
\text { state }\end{array}$} & \multicolumn{11}{|c|}{$\begin{array}{l}\text { Shares by invoicing currency - Extra-EU trade by non-EMU member state (in \%) } \\
\text { - Part } 1\end{array}$} \\
\hline & \multirow{2}{*}{$\begin{array}{l}\text { Invoicing } \\
\text { currency }\end{array}$} & \multicolumn{2}{|c|}{2010} & \multicolumn{2}{|c|}{2012} & \multicolumn{2}{|c|}{2014} & \multicolumn{2}{|c|}{2016} & \multicolumn{2}{|c|}{2018} \\
\hline & & Imports & Exports & Imports & Exports & Imports & Exports & Imports & Exports & Imports & Exports \\
\hline \multirow{4}{*}{ Bulgaria } & EUR & 26.4 & 43.2 & 23.9 & 36.7 & 29.7 & 41.7 & 36.4 & 45.8 & 36.7 & 46.7 \\
\hline & USD & 71.9 & 54.5 & 65.0 & 60.6 & 68.4 & 54.7 & 60.5 & 51.7 & 61.6 & 51.3 \\
\hline & $\begin{array}{l}\text { EU national } \\
\text { currencies }\end{array}$ & 0.7 & 0.7 & 1.6 & 0.6 & 0.8 & 1.1 & 1.7 & 0.5 & 0.4 & 0.6 \\
\hline & Other & 1.1 & 1.7 & 9.4 & 2.1 & 1.0 & 2.5 & 1.4 & 1.9 & 1.3 & 1.5 \\
\hline \multirow{4}{*}{ Czechia } & EUR & 23.7 & 50.5 & 26.5 & 50.5 & 31.1 & 49.5 & 32.7 & 49.3 & 27.2 & 49.7 \\
\hline & USD & 67.7 & 34.2 & 67.3 & 33.5 & 63.2 & 34.3 & 51.2 & 36.2 & 52.9 & 34.7 \\
\hline & $\begin{array}{l}\text { EU national } \\
\text { currencies }\end{array}$ & 3.9 & 4.1 & 2.3 & 3.3 & 2.0 & 3.1 & 11.5 & 3.0 & 15.8 & 2.9 \\
\hline & Other & 4.7 & 11.3 & 3.8 & 12.8 & 3.7 & 13.1 & 4.6 & 11.5 & 4.2 & 12.7 \\
\hline \multirow{4}{*}{ Croatia } & EUR & NA & NA & NA & NA & 38.3 & 73.7 & 49.1 & 66.6 & 53.1 & 70.2 \\
\hline & USD & NA & NA & NA & NA & 58.0 & 12.9 & 48.6 & 21.9 & 44.8 & 19.7 \\
\hline & $\begin{array}{l}\text { EU national } \\
\text { currencies }\end{array}$ & NA & NA & NA & NA & 2.4 & 11.4 & 1.3 & 8.4 & 1.0 & 7.1 \\
\hline & other & NA & NA & NA & NA & 1.3 & 2.1 & 1.0 & 3.1 & 1.1 & 3.1 \\
\hline \multirow{4}{*}{ Denmark } & EUR & 24.0 & 22.8 & 22.1 & 22.3 & 21.4 & 22.7 & 23.8 & 21.1 & 22.8 & 22.9 \\
\hline & USD & 51.4 & 29.6 & 58.0 & 33.7 & 51.1 & 33.2 & 46.5 & 33.6 & 45.9 & 32.4 \\
\hline & $\begin{array}{l}\text { EU national } \\
\text { currencies }\end{array}$ & 12.3 & 19.2 & 11.6 & 18.3 & 12.7 & 16.4 & 14.8 & 16.5 & 13.9 & 16.3 \\
\hline & Other & 12.3 & 28.3 & 8.3 & 25.8 & 14.8 & 27.6 & 14.9 & 28.8 & 17.4 & 28.4 \\
\hline \multirow{4}{*}{ Hungary } & EUR & 29.5 & 48.6 & 22.7 & 44.4 & 26.5 & 50.0 & 32.5 & 52.0 & 40.0 & 54.5 \\
\hline & USD & 63.4 & 40.6 & 70.7 & 37.2 & 67.2 & 30.7 & 59.9 & 28.6 & 51.7 & 27.0 \\
\hline & $\begin{array}{l}\text { EU national } \\
\text { currencies }\end{array}$ & 3.4 & 1.8 & 4.4 & 9.1 & 4.5 & 10.3 & 4.8 & 10.2 & 5.7 & 7.7 \\
\hline & Other & 3.6 & 9.1 & 2.2 & 9.3 & 1.8 & 8.9 & 2.8 & 9.1 & 2.6 & 10.7 \\
\hline \multirow{4}{*}{ Poland } & EUR & 20.0 & 57.4 & 18.4 & 59.0 & 21.6 & 57.4 & 27.3 & 55.8 & 26.9 & 55.0 \\
\hline & USD & 67.0 & 29.4 & 68.6 & 28.0 & 67.2 & 27.8 & 60.8 & 27.7 & 62.2 & 27.9 \\
\hline & $\begin{array}{l}\text { EU national } \\
\text { currencies }\end{array}$ & 10.7 & 7.8 & 11.5 & 7.3 & 9.4 & 7.8 & 8.9 & 7.8 & 7.8 & 7.5 \\
\hline & other & 2.3 & 5.3 & 1.6 & 5.7 & 1.9 & 7.1 & 3.0 & 8.7 & 3.1 & 9.6 \\
\hline \multirow{4}{*}{ Romania } & EUR & 35.2 & 52.1 & 37.2 & 52.0 & 34.2 & 51.4 & 43.5 & 56.6 & 43.3 & 56.5 \\
\hline & USD & 59.5 & 41.4 & 57.2 & 40.6 & 60.7 & 39.3 & 51.3 & 33.7 & 52.5 & 34.7 \\
\hline & $\begin{array}{l}\text { EU national } \\
\text { currencies }\end{array}$ & 3.2 & 0.5 & 3.7 & 0.8 & 3.3 & 1.1 & 3.4 & 2.3 & 2.0 & 1.7 \\
\hline & Other & 2.0 & 6.0 & 2.0 & 6.6 & 1.8 & 8.1 & 1.8 & 7.4 & 2.1 & 7.0 \\
\hline \multirow{4}{*}{ Sweden } & EUR & 10.4 & 23.9 & 17.3 & 23.3 & 20.3 & 20.5 & 14.2 & 16.8 & 12.7 & 19.9 \\
\hline & USD & 39.7 & 11.8 & 58.1 & 27.7 & 54.4 & 35.0 & 48.8 & 37.9 & 53.2 & 34.5 \\
\hline & $\begin{array}{l}\text { EU national } \\
\text { currencies }\end{array}$ & 31.7 & 47.6 & 16.0 & 30.0 & 16.1 & 21.6 & 15.7 & 21.1 & 14.2 & 18.8 \\
\hline & Other & 18.2 & 16.7 & 8.6 & 19.0 & 9.2 & 22.9 & 21.3 & 24.2 & 19.9 & 26.8 \\
\hline
\end{tabular}




\begin{tabular}{|c|c|c|c|c|c|c|c|c|c|c|c|}
\hline \multirow{3}{*}{$\begin{array}{l}\text { Member } \\
\text { state }\end{array}$} & \multicolumn{11}{|c|}{$\begin{array}{l}\text { Shares by invoicing currency - Extra-EU trade by non-EMU member state (in \%) } \\
\text { - Part } 2\end{array}$} \\
\hline & \multirow{2}{*}{$\begin{array}{l}\text { Invoicing } \\
\text { currency }\end{array}$} & \multicolumn{2}{|c|}{2010} & \multicolumn{2}{|c|}{2012} & \multicolumn{2}{|c|}{2014} & \multicolumn{2}{|c|}{2016} & \multicolumn{2}{|c|}{2018} \\
\hline & & Imports & Exports & Imports & Exports & Imports & Exports & Imports & Exports & Imports & Exports \\
\hline \multirow{4}{*}{$\begin{array}{l}\text { United } \\
\text { Kingdom }\end{array}$} & EUR & 5.2 & 3.6 & 4.1 & 3.5 & 5.2 & 3.3 & 4.6 & 3.2 & 5.4 & 3.6 \\
\hline & USD & 65.3 & 31.4 & 67.2 & 33.8 & 66.4 & 35.9 & 67.5 & 35.6 & 66.3 & 44.7 \\
\hline & $\begin{array}{l}\text { EU national } \\
\text { currencies }\end{array}$ & 25.2 & 61.4 & 20.5 & 59.6 & 23.2 & 57.1 & 20.6 & 57.4 & 21.9 & 43.9 \\
\hline & Other & 4.3 & 3.6 & 8.2 & 3.1 & 5.2 & 3.7 & 7.2 & 3.8 & 6.5 & 7.7 \\
\hline \multirow{4}{*}{$\begin{array}{l}\text { Non-EMU } \\
\text { average }\end{array}$} & EUR & 21.8 & 37.8 & 21.5 & 36.5 & 25.4 & 41.1 & 29.3 & 40.8 & 29.8 & 42.1 \\
\hline & USD & 60.7 & 34.1 & 64.0 & 36.9 & 61.8 & 33.8 & 55.0 & 34.1 & 54.6 & 34.1 \\
\hline & $\begin{array}{l}\text { EU national } \\
\text { currencies }\end{array}$ & 11.4 & 17.9 & 9.0 & 16.1 & 8.3 & 14.4 & 9.2 & 14.1 & 9.2 & 11.8 \\
\hline & Other & 6.1 & 10.3 & 5.5 & 10.6 & 4.5 & 10.7 & 6.4 & 10.9 & 6.5 & 11.9 \\
\hline
\end{tabular}

Source: own based on Eurostat (2019)

monitored economies - or this notional block of economies as a whole - can be identified.

As far as the methods of work are concerned, regression analysis is used to test the hypothesis $H 1$. Within this framework, there is always sought a possible statistically significant model, which most accurately describes the possible dependence between the explanatory and the explained variable (GDP vs. a share of invoicing currency for 2018).

In the case of the hypothesis $H 2$, the relationship between the ordinal and the numerical variable (the degree of exchange rate determination by a market and the share of the invoicing currency) is analyzed. Thus, the Pearson correlation coefficient is employed. The determination of the degree of exchange rate flexibility is based on the IMF Annual Report on Exchange Arrangements and Exchange Restrictions 2018 (IMF, 2019). Thus, in the framework of this analysis is worked with currency board (Bulgaria), conventional peg (i.e. ERM II; Denmark), stabilized arrangement (Croatia), floating (the Czech Republic, Hungary, and Romania), and free floating (Poland, Sweden, and the United Kingdom). Numbers from 1 to 5 are assigned to each type of exchange rate arrangements.

Finally, in the case of $R Q 1$, when the years 2010-2018 are compared (all 9 nonEMU countries, or 8 countries for 2010 and 2012 , when Croatia was not yet a member of the EU), the trajectory of the euro and national currencies is evaluated using averages.

\section{Research Results}

As far as the research results are concerned, they are presented in the order in which the research hypotheses were presented. That is, the relationship between the size of the economy (independent variable) and the percentage share of the invoicing currency (dependent variable) was analyzed first. Subsequently, the results concerning the relationship between the exchange rate determination and the share of the invoicing currency are presented. Finally, the results of analysis of the development of averages over time are presented.

\subsection{Invoicing Currency and GDP}

For the presentation of $\mathrm{H} 1$ testing results, the graphical design was chosen (see Fig. 2). The analysis shows that the size of the economy has an impact on invoicing in EUR and national currencies (NC). Respectively, the hypothesis $\mathrm{H} 1$ on the independence between the size of GDP and the share of invoicing in EUR or NC was rejected at $\alpha=5 \%$ (for the effect of GB on the analysis results, see the text below).

In the case of invoicing in EUR, both imports and exports show an indirect relationship between the invoicing currency and the size of GDP. I.e. the larger the GDP, the smaller the share of the euro as the invoicing currency. Both in the case of import and export, the most appropriate model is the exponential relationship ( $p$-value $=0.001$ resp. 0.000) . For imports, the model captures $79 \%$, and 


\section{Finance}

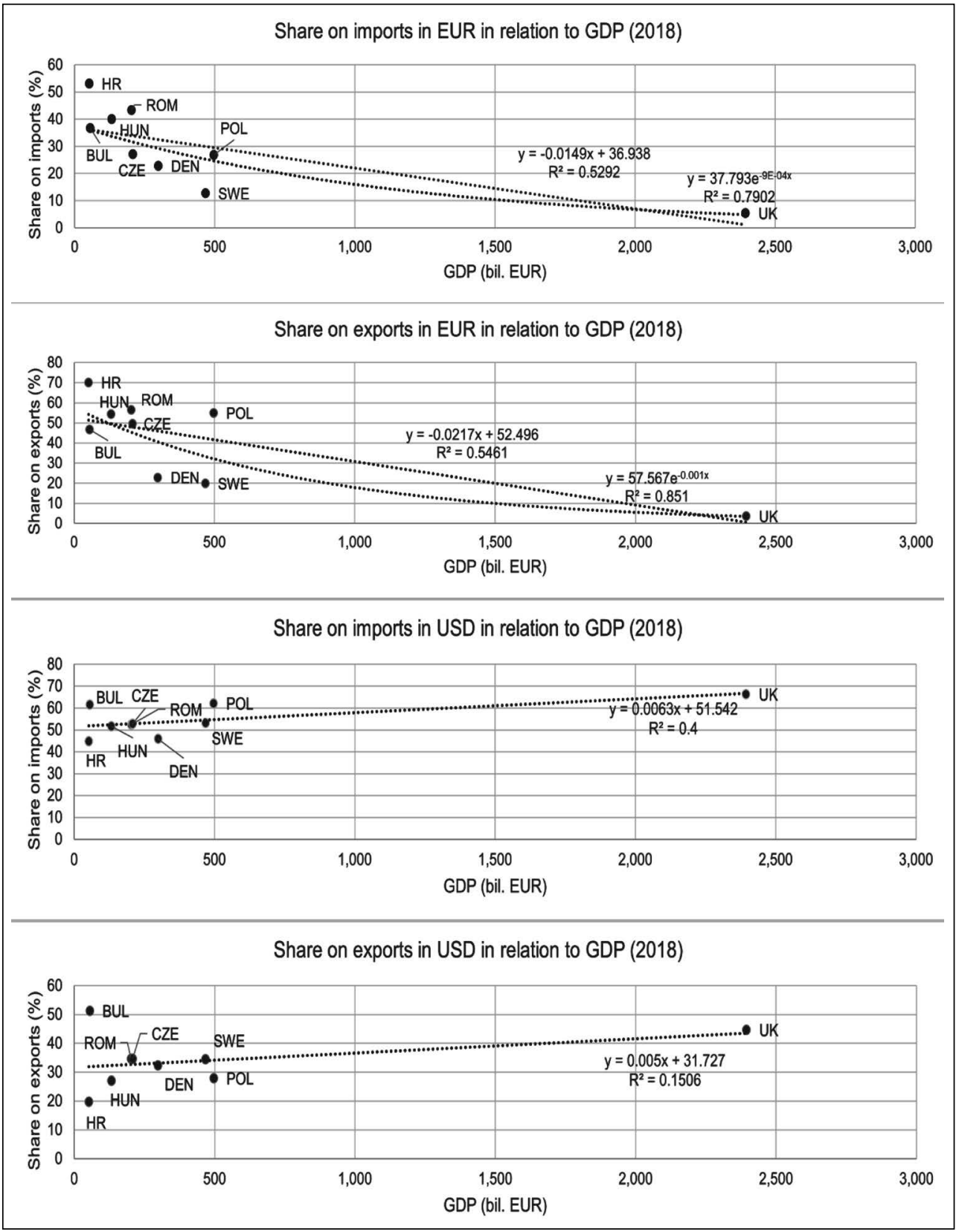




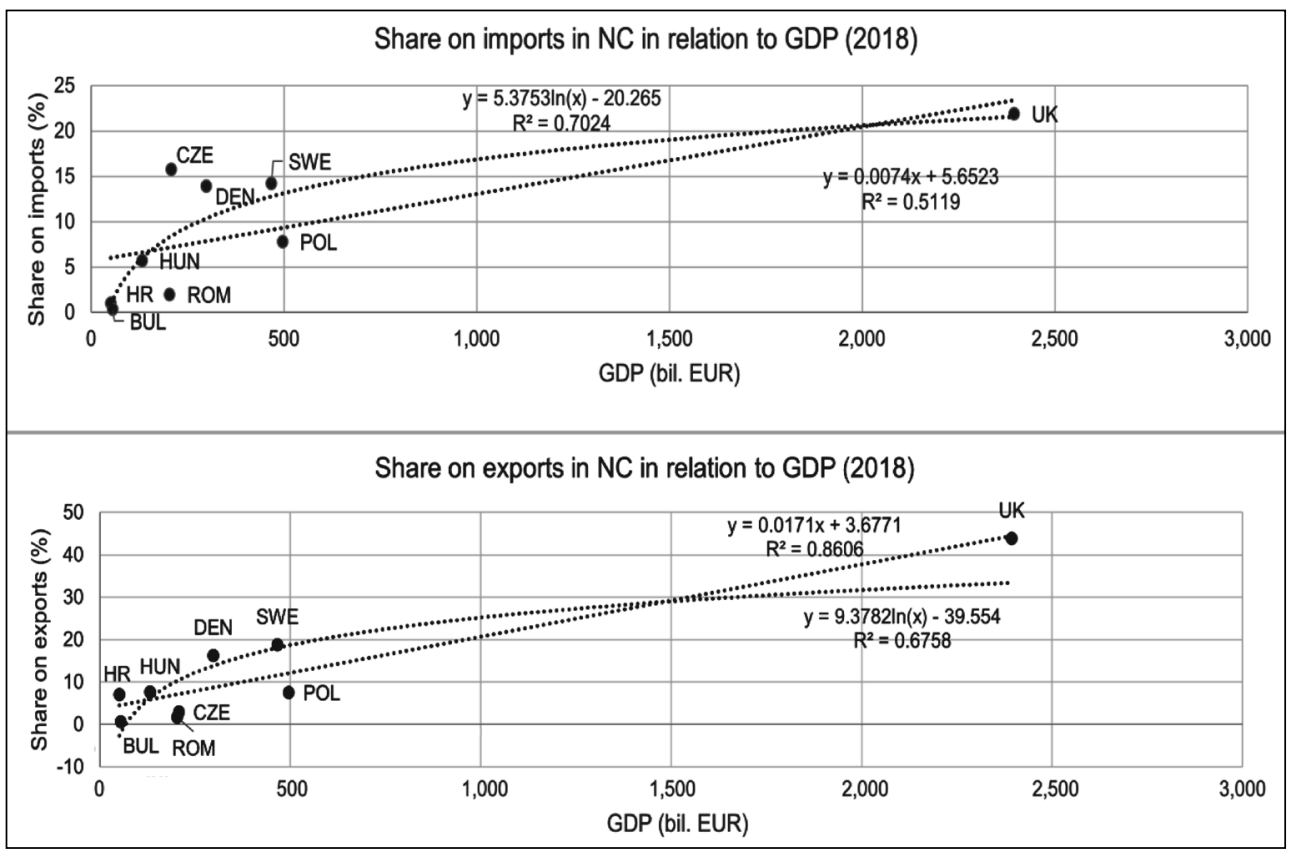

Source: own

for exports even $85 \%$ of the variability of the dependent variable.

As for invoicing in $\mathrm{NC}$, here is the relationship actually inverse to invoicing in EUR. I.e. NC's share in invoicing increases both in import and export as GDP grows (see Fig. 2). The relationship between NC's share of the invoicing currency and GDP is well represented by the logarithmic function. For imports, the model describes $70 \%$, and for exports $67.6 \%$ variability of the dependent variable ( $p$-value $=0.005$, resp. 0.007). Thus, the accuracy of NC models is lower, but still significant, compared to the EUR situation. In addition, in the case of exports invoiced in NC, a straight line would even better capture the relationship with GDP ( $p$-value $=0.000$ and $\mathrm{R} 2=0.861$ ). Poland's position can be noticed from the graphs or residual calculations for EUR and NC. As the second largest economy of the sample, Poland does not fit into theoretical models. The theoretical share of the euro in invoicing should be considerably lower in relation to the output of the economy, while the share of the national currency (Polish zloty - PLZ) should be significantly higher. This situation points to the weak position of the Polish zloty as an invoicing currency when exporting to countries outside the EU. The share of PLZ in imports even steadily decreases in 2010-2018 (-2.9 p.p.), while the share of EUR increases (+6.9 p.p.). In the case of exports, the situation is not that clear (PLZ -0.3 p.p.; EUR -2.4 p.p.) - here, the decline in both currencies is offset by an increase in the ratio of invoicing in other currencies (+4.3 p.p.).

Finally, as far as invoicing in US dollar and GDP are concerned, the null hypothesis of independence between the explanatory and the explained variable cannot be rejected at the 5\% significance level. In this case, the dependence has not been proven.

Last but not least, to the influence of GB on the results of $H 1$ hypothesis testing. In general, it is not very appropriate to include a single point in the analysis that is far from other observations. After examining the results of tests without GB, it was found that the results differ mainly for exports in EUR and NC, when the above-mentioned dependence cannot be observed. For imports invoiced in EUR or NC, 
the situation mainly changes in model accuracy. R2 for exponential (invoicing in EUR) drops to 0.624. R2 for the logarithmic function drops to 0.511 . After the omission of Great Britain, a large influence on the (in)accuracy of the models is caused mainly due to Poland, which does not behave as expected (see Fig. 2).

\subsection{Invoicing Currency and the Exchange Rate Arrangement}

In finding the correlation between these two variables, it is obviously not possible to say that one variable is dependent and the other independent. It can be probably argued that if the exchange rate is fixed in a foreign currency, it is indifferent for businesses to choose which currency to choose as the invoicing currency this is what Denmark appears to be. Similarly, it may be argued that a high exposure to foreign currency requires as much as possible to fix the exchange rate, or to minimize exchange rate fluctuations, and that is why the appropriate exchange rate regime is maintained by the central authority - this is how Croatia appears.

In any case, the assumptions remain as they were defined for hypothesis $\mathrm{H} 2$ in subchapter 3.2 , i.e. 'The more the exchange rate is set by the market ( $\min =$ currency board; $\max =$ free floating), the smaller the share of EUR or USD.' and 'The more the exchange rate is set by the market ( $\min =$ currency board; $\max =$ free floating), the greater the share of the national currency (NC).'

Based on the correlation analysis, a statistically significant relationship was found at $\alpha=5 \%$ in the case of the pair 'exchange rate arrangement' and 'EUR share in imports' (Pearson correl. $=-0.827 ; p$-value $=0.006)$, as well as of the pair 'exchange rate arrangement' and 'EUR share in exports' (Pearson correl. $=-0.696 ; p$-value $=0.037$ ) and finally of the pair 'exchange rate arrangement' and 'NC share in imports' (Pearson correl. $=0.680$; p-value $=0.044)$. In these three variants, the zero hypothesis $\mathrm{H} 2$ is therefore rejected and the alternative hypothesis is accepted. That is, there is a statistically significant relationship between the two analyzed variables. In other words, the less the exchange rate is given by the market (the more it is fixed), the greater the share of EUR in invoicing of imports/exports and vice versa (the correlation coefficient is negative). In the case of imports invoiced in $\mathrm{NC}$, the assumption is also confirmed, i.e. the more the exchange rate is determined on the market, the higher the share of NC in invoicing (the correlation coefficient is positive). Conversely, in the case of exports invoiced in $\mathrm{NC}$, the zero hypothesis $\mathrm{H} 2$ cannot be rejected (Pearson correl. $=0.463 ;$-value $=0.210$ ), i.e. the dependence has not been proven by the test. Finally, there was found no statistically significant relationship between the exchange rate arrangement and the share of imports or exports invoiced in USD. This result should have been actually supposed to be because the exchange rate arrangement of the non-EMU countries concerned is set in relation to EUR, not USD.

At the same time, the results provide some information about the inverse position of NC and EUR (if one increases, the other decreases) and about the vague position of US dollar invoicing. Therefore, a separate EUR-NC test was performed. The results of the correlation analysis confirm a statistically significant inverse relationship for both imports (Pearson correl. $=-0.898 ; p$-value $=0.001$ for the year 2018 and Pearson correl. $=-0.925$; $p$-value $=0.000$ for the year 2014) and exports (Pearson correl. $=-0.847 ; p$-value $=0.004$ for the year 2018 and Pearson correl. $=-0.753$; $p$-value $=0.019$ for the year 2014). A similar statistically significant relationship between EUR and USD or between NC and USD was not identified by the test.

\subsection{Trends in Average Shares of Invoicing Currencies}

Based on the data from Tab. 2 the figure below (Fig. 3) graphically presents the averages of the euro, US dollar, and NC shares on invoicing of non-EMU countries in individual years. Imports and exports are divided. This is a similar output as Fig. 1, only in this case data are presented only for non-EMU countries.

Fig. 3 shows the following: First, regarding imports, in the period under review, the share of USD is falling steadily (USD 2010-2018 = -6.1 p.p.; if we fit the values over time with a straight line, it would have a slope of $-2.13, \mathrm{R} 2=0.64$ ). On the other hand, the share of EUR has been growing steadily (+8 p.p.; if we fit the values over time with a straight line, it would have a slope of $+2.38, \mathrm{R} 2=0.90)$ and the share of NC has fallen only slightly ( -2.2 p.p.; slope $-0.42, \mathrm{R} 2=0.31$ ). Share of other currencies - not shown in Fig. 3 - is practically stable. Similar to the figures for 


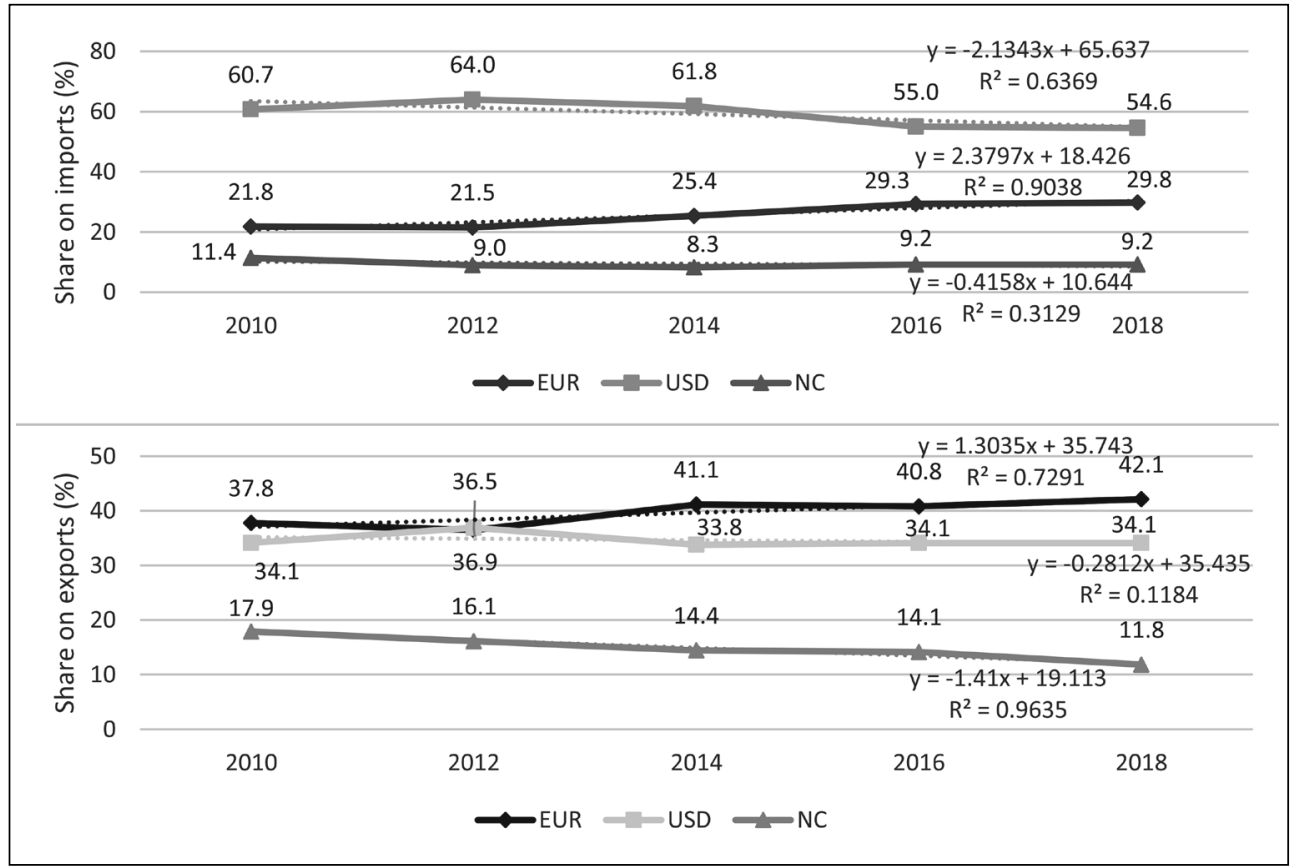

Source: own

the EU as a whole (see Fig. 1), the US dollar dominates. Even in this case, there can be expected significant influence of oil and natural gas, which are traditionally traded in USD. As for exports, the euro is already prevailing over the US dollar, with a slight fluctuation in 2012. In terms of trends, the share of the euro only slightly increases (EUR 2010-2018 = +4.3 p.p.; slope +1.3 , R2 $=0.73$ ), and the USD share is practically stable. NCs decrease more markedly and steadily ( -6.1 p.p.; slope $-1.41, \mathrm{R} 2=0.96)$. Other currencies got slightly (not captured in the graph).

In summary, for both import and export there can be said that especially the euro tend to have a stronger position in the given period. The US dollar and national currencies rather tend to lose their position. Thus, the abovestated research question has been answered.

\section{Discussion}

Corporations involved in international trade strive to minimize exchange rate risk. One way to reduce risk is to choose an invoicing currency. And this article was focused on the choice of the invoicing currency as a possible manifestation of euroization.

However, the manifestations of euroization also take other forms - see, e.g., Ivanov et al. (2011). These authors paid their attention to the bank deposits and loans in the Croatian economy and the possible causes of changes in their amount. In contrast to this contribution, on the one hand, they follow an overlap into all parts of the economy, on the other hand, they are focused only on Croatia. Moreover, Croatia has traditionally been a very euroized country because of the historically low quality of the local currency, the Croatian kuna. Therefore, the variables affecting euroization, which Ivanov et al. (2011) follow, are, say, traditional i.e. exchange rate, exchange rate volatility, real effective exchange rate and inflation. But since the research presented here contains a sample of economies with differently 'good' currencies, the effort was to find other relationships (GDP volume, exchange rate arrangement). 
Concerning a similarly focused research, Lighart and Werner (2012) observe practically similar conclusions on the case of Norway as this paper offers. The euro is pushing itself as an invoicing currency at the expense of the Norwegian kroner (NOK) and also occupies a position of vehicle currency instead of the US dollar. Comparison with the conclusions of Lighart and Werner is also beneficial due to the quality of the NOK, which does not suffer from historical symptoms (high inflation) such as the aforementioned Croatian kuna or the Polish zloty. Low inflation is mentioned by Lighart and Werner as an explanatory variable of the effect on the euroization of invoicing in Norway.

However, whatever approach to research is chosen, the conclusions on euroization or de-euroization always aim at the quality of the economic policies pursued, i.e. to a stable macroeconomic environment (Bošnjak, 2018; Ivanov et al., 2011). Therefore, following Tab. 1, it seems no coincidence that the population of countries with a traditionally good macroeconomic environment (de facto good currency), such as Sweden and the Czech Republic, do not have much support for replacing their national currency with the euro. Greater willingness to euroization can thus still be expected mainly in those economic areas where the use of the euro is not only economically reasonable but also comfortable. And such an area may be international trade with intensive ties to euro-paying countries. However, or perhaps therefore, as Friberg and Wilander (2008, p. 68) mention in their findings, Swedish exporters most often used the local currency - the Swedish krona - at the time of the data collection for the 2006 survey (At that time, the euro as a currency had a fairly short history and moreover, traditional countries such as Norway, Denmark, the UK, the USA, China are traditional important trading partners. That is, countries that do not have the euro as their legal tender.). And although according to Tab. 2 the share of the national currency in Swedish exports (as well as imports) clearly decreased, this decline was not in favor of the euro, but rather in favor of other national currencies and USD.

\section{Conclusions}

According to available Eurostat data on import and export and invoicing currency of non-EMU states to third countries expressed in EUR,
USD, national and other currencies, it was found that the block of EU countries not yet using the euro as their sole legal tender rather euroizes in terms of international trade invoicing.

The level of growth in the share of the euro and the decline in the national currency has a different intensity for imports and another for exports. At the same time, it was found that for imports in EUR and NC and exports in EUR, a statistically significant correlation between the currency of the invoicing and the exchange rate regime could be identified. Last but not least, it has been found that for invoicing in EUR and $\mathrm{NC}$, there is a relationship between the size of GDP and the currency of invoicing. In the case of EUR, the relationship is indirect - the smaller the economy, the greater the euro's share of invoicing and vice versa. The progress of the relationship is best captured by the exponential function. In the case of NC, this relationship is direct - the smaller the economy, the smaller the share of NC and vice versa. In this case, the progress of the relationship is best captured by the logarithmic function. No statistically significant model was identified for US dollar invoicing in relation to the size of the economy.

The above-mentioned shows that, especially in smaller economies, the ability and will of (domestic) companies to push through the national currency as invoicing is limited. At the same time, the position of Poland can be emphasized. Although Poland is not a small economy in terms of GDP, the ability or willingness of Polish firms to invoice in the Polish zloty is rather low. The invoicing of Polish international trade will also be undoubtedly influenced by hysteresis; i.e. the behavior of the dynamic system is influenced not only by the current variables, but also by the initial situation - in the case of Poland, historically high inflation during the period of economic transformation.

This research neglects some of the potential drivers of both corporate euroization and deeuroization. At the macro level, for example, it may be the development of the terms of trade between EUR and NC (exchange rate development), or other economic indicators traditionally mentioned in relation to the OCA theory, i.e. the inflation rate or interest rates. At the micro-level, it may be for example the ability to transfer exchange rate risk to another entity, or the very attitude of business owners or business management to the euro as such. These effects may therefore be subject to 
further study. At the microeconomic level, the challenge is to obtain information similar to the one analyzed in this article, but this time for intra-EU trade, or information on trade and its settlement in EUR directly within a particular national economy.

Finally, the information gathered in the research presented here can be used by policymakers whether to argue for more euroization or de-euroization, for businesses and their future approach to exchange rate risk management and for example for banks and other financial institutions that offer currency hedging and conversion.

Acknowledgment: The work was supported by the internal project "SPEV - Investments under the Industry 4.0 concept", 2020, University of Hradec Králové, Faculty of Informatics and Management, Czech Republic.

\section{References}

Beckmann, E., \& Stix, H. (2015). Foreign currency borrowing and knowledge about exchange rate risk. Journal of Economic Behavior \& Organization, 112, 1-16. https://doi. org/10.1016/j.jebo.2014.12.015

Bošnjak, M. (2018). Financial eurization in Croatia and its (non)linear pattern behaviour. Croatian Operational Research Review, 9(1), 51-62. https://doi.org/10.17535/ crorr.2018.0005

Bun, M. J. G., \& Klaasen, F. J. G. M. (2007). The Euro Effect on Trade is not as Large as Commonly Thought. Oxford Bulletin of Economics and Statistics, 69(4), 473-496. https://doi.org/10.1111/j.1468-0084.2007.00448.x

Croatian National Bank. (2015). Monetary Policy Framework. Zagreb: Croatian National Bank. Retrieved November 11, 2019, from https://www.hnb.hr/en/core-functions/ monetary-policy/monetary-policy-framework

De Grauwe, P. (2016). The legacy of the Eurozone crisis and how to overcome it. Journal of Empirical Finance, 39(B), 147-155. https://doi.org/10.1016/j.jempfin.2016.01.015

De Grauwe, P. (2018). Economics of Monetary Union (12th ed.). Oxford: Oxford University Press.

Dosi, G., Minenna, M., Roventini, A., \& Violi, R. (2019). Making the Eurozone work: A risk-sharing reform of the European Stability Mechanism. Annals of Operations Research, 1-41. https://doi. org/10.1007/s10479-019-03325-9
Eurostat. (2019). Extra-EU trade in goods by invoicing currency. Euro was the most used currency for EU exports and US dollars for EU imports in 2018. Luxembourg: Eurostat Press Office. Retrieved November 6, 2019, from https://ec.europa.eu/eurostat/ documents/2995521/9795759/6-20052019-APEN.pdf/9fc63999-3e64-4cf9-99c3-eac4e18b7cf4

Flash Eurobarometer. (2019). Opinion polls in Member States yet to adopt the euro. 2013-2019. Retrieved February 4, 2020, from https://ec.europa.eu/info/about-europeancommission/euro/public-opinion-euro_en

Goldberg, L. S., \& Tille, C. (2008). Vehicle currency use in international trade. Journal of International Economics, 76(2), 177-192. https://doi.org/10.1016/j.jinteco.2008.07.001

Horníková, M., Hurník, J., \& Kotlán, V. (2005). Spontaneous euroization in the Czech Republic (is it a problem and why not?). Prague Economic Papers, 14(2), 99-108. https://doi. org/10.18267/j.pep.255

IMF. (2019). Annual Report on Exchange Arrangements and Exchange Restrictions 2018. Washington, DC: International Monetary Fund. Retrieved from https://www.imf.org

Ito, T., Koibuchi, S., Sato, K., \& Shimizu, J. (2016). Choice of Invoice Currency in Japanese Trade: Industry and Commodity Level Analysis (REITI Discussion Paper 16-E-031). Tokyo: The Research Institute of Economy, Trade and Industry.

Ivanov, M., Tkalec, M., \& Vizek, M. (2011). The Determinants of Financial Euroization in a Post-Transition Country: Do Threshold Effects Matter? Finance a úvěr - Czech Journal of Economics and Finance, 61(3), 230-251.

Knížková, J. (2018, July 18). Prijetí eura? Obavy mají predevším menši podnikatelé a firmy. Podnikatel.cz. https://www.podnikatel. cz/clanky/prijeti-eura-obavy-maji-predevsimmensi-podnikatele-a-firmy/

Ligthart, J. E., \& Werner, S. E. V. (2012). Has the euro affected the choice of invoicing currency? Journal of International Money and Finance, 31(6), 1551-1573. https://doi. org/10.1016/j.jimonfin.2012.02.015

Mačí, J. (2019). Current State of Euroization in non-EMU Countries. In Proceedings of the 13th International Scientific Conference INPROFORUM, 100 Years of the Koruna (pp. 211-217). České Budějovice: University of South Bohemia in České Budějovice, Faculty of Economics. 


\section{Finance}

Mika, A., \& Zymek, R. (2018). Friends without benefits? New EMU members and the "Euro Effect" on trade. Journal of International Money and Finance, 83, 75-92. https://doi. org/10.1016/j.jimonfin.2018.02.001

Rochon, L.-P., \& Rossi, S. (2003). Dollarization out, Euroization in. International Journal of Political Economy, 33(1), 21-41.

Rose, A. K. (2000). One money, one market: the effect of common currencies on trade. Economic Policy, 15(30), 7-45. https://doi.org/10.1111/1468-0327.00056
Udoh, E. A. P., \& Udeaja, E. A. (2019). Asymmetric effects of financial dollarization on nominal exchange rate volatility in Nigeria. The Journal of Economic Asymmetries, 19, e00118. https://doi.org/10.1016/j.jeca.2019.e00118

Xhelili, A., Hashi, I., \& Toci, V. (2016). A Qualitative Exploration of Euroization and Its Risks at Bank Level. Ekonomska Misao i Praksa - Economic Thought and Practice, 25(2), 397-420. 